\title{
Bathymetry from space: Rationale and requirements for a new, high- resolution altimetric mission
}

\section{Bathymétrie spatiale : arguments en faveur d'une nouvelle mission altimétrique " haute résolution »}

\author{
David T. Sandwell ${ }^{a,{ }^{*}}$ Walter H.F. Smith ${ }^{b}$, Sarah Gille ${ }^{a}$, Ellen Kappel ${ }^{c}$, Steven Jayne ${ }^{d}$, Khalid \\ Soofi ${ }^{\mathrm{e}}$, Bernard Coakley ${ }^{\dagger}$ and Louis Géli ${ }^{\mathrm{g}}$ \\ aScripps Institution of Oceanography, La Jolla, CA 92093-0225, USA \\ b Laboratory for Satellite Altimetry, NOAA, Silver Spring, MD 20910-3282, USA \\ ${ }^{c}$ Geoscience Professional Services, Bethesda, MD, USA \\ ${ }^{\mathrm{d} D e p a r t m e n t}$ of Physical Oceanography, Woods Hole Oceanographic Institute, Woods Hole, MA \\ 02543, USA \\ e Conoco Inc., 600 North Dairy Ashford, Houston, TX 77252-2197, USA \\ 'Geophysical Institute, University of Alaska, Fairbanks, AK 99775, USA \\ gIFREMER, Marine Geosciences' Department, BP 70, 29280 Plouzané, France \\ *: Corresponding author : dsandwell@ucsd.edu
}

\begin{abstract}
Bathymetry is foundational data, providing basic infrastructure for scientific, economic, educational, managerial, and political work. Applications as diverse as tsunami hazard assessment, communications cable and pipeline route planning, resource exploration, habitat management, and territorial claims under the Law of the Sea all require reliable bathymetric maps to be available on demand. Fundamental Earth science questions, such as what controls seafloor shape and how seafloor shape influences global climate, also cannot be answered without bathymetric maps having globally uniform detail. Current bathymetric charts are inadequate for many of these applications because only a small fraction of the seafloor has been surveyed. Modern multibeam echosounders provide the best resolution, but it would take more than 200 ship-years and billions of dollars to complete the job. The seafloor topography can be charted globally, in five years, and at a cost under \$ 100 M. A radar altimeter mounted on an orbiting spacecraft can measure slight variations in ocean surface height, which reflect variations in the pull of gravity caused by seafloor topography. A new satellite altimeter mission, optimized to map the deep ocean bathymetry and gravity field, will provide a global map of the world's deep oceans at a resolution of 6-9 km. This resolution threshold is critical for a large number of basic science and practical applications, including:
\end{abstract}

- determining the effects of bathymetry and seafloor roughness on ocean circulation, mixing, climate, and biological communities, habitats, and mobility;

- understanding the geologic processes responsible for ocean floor features unexplained by simple plate tectonics, such as abyssal hills, seamounts, microplates, and propagating rifts; 
- improving tsunami hazard forecast accuracy by mapping the deep-ocean topography that steers tsunami wave energy;

- mapping the marine gravity field to improve inertial navigation and provide homogeneous coverage of continental margins;

- providing bathymetric maps for numerous other practical applications, including reconnaissance for submarine cable and pipeline routes, improving tide models, and assessing potential territorial claims to the seabed under the United Nations Convention on the Law of the Sea.

Because ocean bathymetry is a fundamental measurement of our planet, there is a broad spectrum of interest from government, the research community, industry, and the general public.

Mission requirements. The resolution of the altimetry technique is limited by physical law, not instrument capability. Everything that can be mapped from space can be achieved now, and there is no gain in waiting for technological advances. Mission requirements for Bathymetry from Space are much less stringent and less costly than typical physical oceanography missions. Long-term seasurface height accuracy is not needed; the fundamental measurement is the slope of the ocean surface to an accuracy of $\mathrm{r} \sim 1 \mu \mathrm{rad}\left(1 \mathrm{~mm} \mathrm{~km}^{-1}\right)$. The main mission requirements are:

- improved range precision (a factor of two or more improvement in altimeter range precision with respect to current altimeters is needed to reduce the noise due to ocean waves);

- fine cross-track spacing and long mission duration (a ground track spacing of $6 \mathrm{~km}$ or less is required. A six-year mission would reduce the error by another factor of two);

- moderate inclination (existing satellite altimeters have relatively high orbital inclinations, thus their resolution of east-west components of ocean slope is poor at low latitudes. The new mission should have an orbital inclination close to $60^{\circ}$ or $120^{\circ}$ so as to resolve north-south and east-west components almost equally while still covering nearly all the world's ocean area);

- near-shore tracking (for applications near coastlines, the ability of the instrument to track the ocean surface close to shore, and acquire the surface soon after leaving land, is desirable).

To cite this article: D.T. Sandwell et al., C. R. Geoscience 338 (2006). 


\section{Résumé}

La profondeur des fonds marins est une donnée essentielle pour un grand nombre de domaines d'activité : scientifique, économique, politique. La bathymétrie - la science de la mesure des profondeurs de l'océan - a des applications aussi diverses que la gestion des ressources minérales et vivantes, l'aménagement des habitats sous-marins, l'implantation des câbles sous-marins et autres pipe-lines, l'extension des juridictions des pays riverains dans le cadre de l'article 76 de la convention des Nations unies sur le droit de la mer, etc. Sur le plan scientifique, des questions d'ordre fondamental - telles que la formation des fonds océaniques ou le rôle du relief sous-marin sur l'évolution du climat - passent par une connaissance globale et homogène de la topographie du plancher océanique. Les cartes globales de bathymétrie actuellement disponibles sont inadaptées pour bon nombre de ces applications, car de vastes zones océaniques demeurent inexplorées. Les sondeurs acoustiques multifaisceaux offrent la résolution adéquate, mais il faudrait plus de 200 années-navire pour couvrir l'ensemble des grands fonds, pour un coût de l'ordre de plusieurs milliards d'euros. En revanche, l'altimétrie satellitaire permettrait d'obtenir un modèle global de bathymétrie satisfaisant pour de nombreuses applications, en moins de six ans, à un coût inférieur à la centaine de millions d'euros. En effet, dans l'océan, les masses d'eau ont tendance à s'accumuler au-dessus des montagnes sous-marines, à cause de l'attraction causée par les reliefs. La surface de l'océan au repos (en l'absence de toute perturbation océanique) correspond au géoïde, une surface équipotentielle en tous points, perpendiculaire à la force de pesanteur locale. Les satellites altimétriques mesurent les variations de hauteur de la surface des océans, donc les ondulations du géoïde, associées aux variations de la topographie sous-marine. Les données altimétriques actuelles, combinées aux données existantes de bateaux, permettent ainsi d'estimer, de manière indirecte, les variations de topographie dans les longueurs d'ondes comprises entre 16 et $160 \mathrm{~km}$. Une nouvelle mission altimétrique, spécifiquement dédiée à la collecte de données gravimétriques " haute résolution », permettrait d'accéder à des longueurs d'onde plus courtes, jusqu'à $r \approx 6 \mathrm{~km}$ environ. Cet article détaille les objectifs pour lesquels ce gain en résolution est essentiel :

- déterminer le rôle de la topographie sous-marine et de la rugosité des fonds sur la circulation globale, les échanges à l'intérieur de la masse d'eau, le climat, les habitats benthiques ;

- comprendre les processus géologiques à l'origine des structures intraplaques, telles que les collines abyssales, les microplaques, les propagateurs et les volcans sous-marins ;

- cartographier le champ de gravité et améliorer les systèmes de navigation inertielle ;

- fournir une couverture gravimétrique « haute résolution », homogène et globale, des marges continentales.

- asseoir les revendications de juridiction dans le cadre de la convention des Nations unies sur le droit de la mer.

La résolution de la gravimétrie satellitaire se heurte à des limitations d'ordre physique (liées à la loi de gravité) et non instrumental. La technologie actuelle permet d'accéder à la résolution ultime de la méthode. Les spécifications techniques d'une mission spécifiquement dédiée à la gravimétrie « haute résolution » et à la bathymétrie sont beaucoup moins contraignantes et moins coûteuses que celles des missions océanographiques. La donnée fondamentale à acquérir est la pente du géoïde, à une précision de l'ordre du microradian $\left(1 \mathrm{~mm} \mathrm{~km}^{-1}\right)$; la détermination ultra-précise de la hauteur de la surface de l'océan n'est pas nécessaire. Pour atteindre la résolution ultime, il est proposé ici :

- d'améliorer la précision de l'altimètre d'un facteur 2 par rapport à ceux qui ont été embarqués sur ERS-1 et GeoSat, ce qui est faisable actuellement, de manière à réduire le bruit dû aux vagues ;

- de densifier les traces, pour porter à 6 km l'espacement à l'équateur ;

- de porter à six ans la durée de la mission, afin de pouvoir réduire le bruit par sommation sur les traces répétitives ; 
- d'incliner les orbites à $60^{\circ}$ (ou $120^{\circ}$ ), de façon à avoir la même précision sur les composantes nordsud et est-ouest de la déflection de la verticale ;

- d'améliorer les performances de l'altimètre près des côtes (celui-ci doit « décrocher » et « raccrocher » au plus près de la terre).

Pour citer cet article : D.T. Sandwell et al., C. R. Geoscience 338 (2006).

Keywords: Bathymetry from space; High-resolution altimetry; Seafloor topography; Major current systems; Ocean mixing rate; Topography/gravity ratio (T/G); Bathymetric models

Mots-clés: Bathymétrie spatiale; Altimétrie « haute résolution »; Topographie des fonds océaniques; Grands courants océaniques; Taux de mélange des masses d'eau; Rapport topographie/gravité (T/G); Modèles bathymétriques 


\section{Mapping the Ocean Floor}

The depth to the ocean floor and the roughness of the bottom vary throughout the oceans as a result of numerous geologic processes [Brown, et al., 1998]. This seafloor topography influences the ocean circulation and mixing that moderate Earth's climate [Kunze and Llewellyn Smith, 2004; Munk and Wunch, 1998], and the biological diversity and food resources of the sea. The ocean floor records the geologic history and activity of the ocean basins [Mueller, et al., 1997], revealing areas that may store resources such as oil and gas [Fairhead, et al., 2001], and generate earthquakes and tsunamis [Mofjeld, et al., 2004]. Despite the importance of Earth's ocean floor to our quality of life, we have made much better maps of the surfaces of other planets, moons, and asteroids.

After five decades of surveying by ships carrying echosounders, most of the ocean floor remains unexplored and there are vast gaps between survey lines (Figure 1). The primary reason for this lack of data is that ships are slow and expensive to operate. For example, a systematic mapping of the deep oceans by ships would take more than 120 years of survey time. Moreover, because the swath width of a multibeam echo sounder is proportional to depth, it takes much longer (750 ship-years) to survey the shallow $(<500 \mathrm{~m})$ continental margins [Carron, et al., 2001]. While shipboard surveys offer the only means for high-resolution seafloor mapping, moderate accuracy and resolution (12-17 km full wavelength) can be achieved using satellite radar altimetry at a fraction of the time and cost (Figure 2). Radar altimeters aboard the ERS-1 and Geosat spacecraft have surveyed the marine gravity field over nearly all of the world's oceans to a high accuracy and moderate spatial resolution of 25-45 km; [Cazenave, et al., 1996; Sandwell and Smith, 1997; Tapley and Kim, 2001]. In the wavelength band 10 to $160 \mathrm{~km}$, variations in gravity anomaly are highly correlated with seafloor topography (Figure 3) and thus, in principle, can be used to recover topography [Baudry and Calmant, 1991; Dixon, et al., 1983; Jung and Vogt, 1992; Ramillien and Cazenave, 1997; Smith and Sandwell, 1994]. The sparse ship soundings constrain the long wavelength (> $160 \mathrm{~km}$ ) variations in seafloor depth and are also used to calibrate the local variations in topography to gravity ratio associated with varying tectonics and sedimentation.

Satellites have another advantage in comparison to the present database of echosoundings, namely globally uniform resolution. By carrying the same sensor all over the globe, a satellite makes measurements of the same quality everywhere, a requirement for mapping the global distribution patterns of bathymetric features. Ships have not done this. The era of frontier exploration, when scientists could take ships into remote areas merely for curiosity's sake, was an era of single-beam echosounders and relatively poor navigation. The last two decades have seen great technical advances in echosounding (multi-beam swath mapping systems, Figure 2) and navigation (Global Positioning System), but these have been deployed over only a few percent of the ocean's area. The focus has been on coastal regions and Exclusive Economic Zones, and research emphasizing "hypothesis testing," which requires ships to revisit previously surveyed areas. The result is that even today, most of the data available in the remote oceans are the oldstyle, low-tech data. 


\section{Sensing Gravity and Bathymetry from Space}

The ocean's surface has broad bumps and dips that reflect variations in the pull of gravity. In the deep ocean where sediments are thin, seafloor features such as seamounts produces minor variations in gravity, which in turn produce tiny variations in ocean surface height (Figure 3). On the shallow continental margins, where sediments are thick and the seafloor is relatively flat, gravity anomalies reflect the structure of the sedimentary basins. Gravity can be measured at orbital altitude using spacecraft such as CHAMP, GRACE , and GOCE [Tapley and Kim, 2001]. However, because these spacecraft measure gravity at altitudes higher than $250 \mathrm{~km}$, they are unable to recover wavelengths shorter than about $160 \mathrm{~km}$. In contrast, satellite altimeters offer much higher spatial resolution gravity measurements because they sense the gravity field at the ocean surface, which is typically only $4 \mathrm{~km}$ above the seafloor. In the deep ocean basins, where sediments are thin and seabed geology is simple, satellite altimeter data may be used to predict bathymetry at a half-wavelength scale of 6-9 km (Figure 3). Existing satellite altimeter data have proved the feasibility of the technique and revealed the overall, large-scale tectonic features of the ocean basins. A properly designed mission using existing technology could bring significant new resolution (Figure 4), capturing a critical scale of features, and facilitating new science and applications.

The radar altimeter measures sea surface bumps and dips by measuring the travel time of microwave pulses. These pulses reflect from an area of ocean surface (footprint) that grows with increasing sea state. For gravity field recovery and bathymetric estimation, along track sea surface height differences (slopes) are needed, instead of absolute heights. The major error source is the roughness of the ocean surface due to ocean waves. This means that a new mission optimized for recovery of gravity and bathymetry can be can be simpler and cheaper than other altimeter missions such as Topex/Poseidon used to measure ocean dynamics and sea-level rise. This is because the absolute height, and any component of height which changes only over wavelengths much longer than a few hundred $\mathrm{km}$, is irrelevant, as it contributes to negligible slope. For example, most of the standard altimeter corrections such as radial orbit error, ionosphere and troposphere delays, and deep ocean tides have slopes less than 1 microradian, which corresponds to a 1-milligal gravity accuracy. Besides having less stringent accuracy requirements, an altimeter optimized for gravity field recovery must have dense ground track coverage. Current altimeters optimized for physical oceanography all have repeating orbits with sparse track coverage and thus do not contribute to the recovery of high-resolution gravity and bathymetry.

\section{New Science}

A new space bathymetry mission would furnish - for the first time - a global view of the ocean floor at the proper scale to enable important progress in basic and applied science. Ocean and climate modelers and forecasters would be able to account for how the ocean bottom steers currents and how bottom roughness controls the mixing of heat, greenhouse gases, and nutrients. The details of the tectonic and volcanic processes that shape the ocean floor could be studied in their full complexity, beyond the over-simplified view given in the plate tectonic theory. The hazards to coastal communities posed by tsunamis could be more realistically assessed, as deep ocean bathymetry focuses and defocuses tsunami wave energy to the extent that coastal wave height can vary by factors of 2-3. 


\section{Ocean Circulation, Mixing, and Climate}

Bathymetry defines the bottom boundary of the ocean. At large scales it determines basic flow patterns of ocean circulation. At small scales it controls the transport of water between ocean basins, and seafloor roughness converts energy from horizontal flows to mix the ocean vertically. Both ocean circulation and mixing play major roles in climate.

The sun fuels Earth's climate system, supplying most of its energy near the equator. The tropics would be painfully hot and high latitudes uninhabitably cold were it not for the atmosphere and ocean, which spread the sun's energy poleward. Both the atmosphere and the ocean contribute roughly equally to the poleward transfer of heat, but the ocean has vastly greater heat storage capacity. The energy required to heat the entire atmosphere by $1{ }^{\circ} \mathrm{C}$ would warm the ocean by less than $0.001^{\circ} \mathrm{C}$. Because the ocean is slow to heat and cool, it moderates climate change.

To evaluate how the ocean influences climate, oceanographers try to understand how the ocean transports and stores climatologically important properties such as heat and carbon dioxide. This requires identifying the routes that water follows as it flows in deep currents along the seafloor, as well as how it mixes with other waters as it moves along. The deepest, densest water in ocean basins results from sinking at high latitudes. Water that has sunk recently contains the most recent signature of the current state of the climate: high concentrations of carbon dioxide, for example, or slightly warmer temperatures than less-recently ventilated water. State-of-the-art ocean models investigate the impact of mixing from overflows over sills and in deep ocean basins through direct simulation and parameterization. Because ocean currents interact with the bottom of the ocean, detailed knowledge of seafloor bathymetry will help improve predictions of the global ocean circulation and heat transport, and thus their effect on climate.

\section{Predicting Ocean Circulation}

Numerical models of the ocean's circulation forecast currents for shipping and military operations, predict climate, provide early warnings for natural disasters, and help us understand the fundamental physics that governs ocean circulation, which in turn helps develop improved forecast models. Bathymetry provides the bottom boundary condition for all types of ocean models [Gille, et al., 2004]. Ocean circulation models are remarkably sensitive to small perturbations in bathymetry. In high-resolution models used to predict oceanic flows, small (25 $\mathrm{km}$ ) topographic features can steer major currents (Figure 5). Other ocean models run for climate prediction show how changes in bathymetry influence poleward heat transport. Ocean climate modelers looked at the impact of changing the depth of the ridge separating the high-latitude Norwegian Sea from the North Atlantic Ocean. In their model, the ocean transports nearly twice as much heat northward when the ridge contains deep passageways. This difference implies significantly different climate regimes. These results show that accurate representation of ridges and canyons is important even for low-resolution climate models, and that topographic features in the deep ocean can steer upper ocean and surface level flows, even when the flow does not intersect topography. 
In the future, accurate high-resolution bathymetry is expected to become a more pressing requirement, as other modeling challenges are solved. In the next ten years, projected increases in computer power will permit global models to simulate eddies and currents with scales of $10 \mathrm{~km}$ or less. New satellite-derived bathymetry will then be needed to give modelers the ocean bottom boundary at the same resolution as the currents and eddies they want to model. This will help to make ocean circulation models that better predict how heat and other water properties move through the ocean to influence climate.

\section{Understanding Ocean Mixing}

Small-scale bathymetry has a large impact on ocean circulation because it influences how water mixes [Polzin, et al., 1997]. Understanding how the ocean mixes is crucial for understanding Earth's climate because vertical mixing determines how quickly heat and carbon dioxide can penetrate into the deep ocean [Jayne, et al., 2004]. Predictions of global sea level rise over the next century differ by $25 \%$ or more depending on the rate of vertical mixing. Most deep-ocean mixing can be attributed to two processes, both of which depend on bathymetry. As water flows through tightly constrained passageways and over sills it rapidly mixes with surrounding water. This mixing affects the concentrations of heat and dissolved gases in seawater and the total quantities that can be stored in the ocean. As a result, in models containing these passageways, small changes to the topography can lead to significant changes in ocean circulation and in the way that heat is transported through the ocean.

Vertical mixing in the deep ocean also controls aspects of the horizontal circulation. Both winddriven and tidal currents generate internal waves when they flow over abyssal topography. These waves subsequently mix the ocean vertically through wave breaking or other mechanisms. Measurements of vertical mixing in the Brazil Basin indicate that mixing rates vary with geographic location and depth, and the energetics of dissipation depend on fine-scale topography in the deep ocean (Figure 6). Models that predict future climate will require accurate bathymetry in order to predict spatially varying mixing rates. Unfortunately, the best global bathymetry that is currently available does not resolve seafloor topography at all length scales. Theoretical studies suggest that bathymetric features as small as $1 \mathrm{~km}$ may influence mixing. A new mission could map the length scales constraining $50 \%$ to $70 \%$ of the tidally driven mixing. Some features that generate internal waves are too small to be visible from space, but they may be predicted statistically, provided that bathymetry is resolved down to lengths where the statistics of roughness may be extrapolated from fractal models $(8 \mathrm{~km}$, Figure 4$)$.

There are still unknown circulation pathways in the ocean, and the best bathymetry cannot yet determine where critical mixing is happening. A factor of two increase in the horizontal scales resolved and a factor of five increase in the signal-to-noise ratio, possible with the proposed satellite mission, will permit many of these currently unknown pathways to be mapped, and areas with topographically enhanced mixing to be found. 


\section{Beyond Plate Tectonics}

The broad architecture and geologic history of the ocean basins can be elegantly explained by plate tectonic theory, which states that Earth's outer rocky layer is divided into a number of rigid blocks called plates. These plates move slowly over Earth's surface. The plate's interiors should be geologically stable and inactive, and earthquakes, volcanoes, and mountain building occur only near plate boundaries. This theory grew up in the 1960s when seafloor bathymetry was relatively crude; evidence came primarily from the geographical pattern of seafloor magnetic anomalies, and the global distribution of earthquakes, volcanoes, and fossils.

In the mid-1990s, satellite altimeter measurements of the marine gravity field provided the first globally uniform and detailed view of ocean floor architecture [Sandwell and Smith, 1997]. This new view seemed to both confirm and complicate plate tectonic theory. The satellite perspective displayed a globally continuous pattern of mid-ocean ridges and fracture zones, as the theory predicted. However, the data also revealed many features that the theory did not anticipatemidocean ridges that propagated into old, thick oceanic lithosphere; spreading centers that overlapped (sometimes forming microplates that rotate rapidly between larger plates for a few million years); and a very complex pattern of volcanic seamounts in the interiors of plates [Wessel and Lyons, 1997]. These new features provide clues to the changing forces applied to the tectonic plates and the geologic history of our planet.

The improved resolution of a new space bathymetry mission will reveal hundreds of small structures on a global basis, and patterns of volcanism and fracturing that are not currently mapped. A more detailed view of the global mid-ocean ridge spreading system will permit a better understanding of what causes ridges to periodically break into segments, what causes the topographic variability displayed at mid-ocean ridges [Smith, 1998] (Figure 4), and whether there is a limit to how fast seafloor can be created at spreading centers [Naar and Hey, 1989]. A clearer view of plate motion over the past 180 million years recorded in the patterns of ocean floor structures [Mueller, et al., 1997] will shed light on the synchroneity of plate reorganizations and plate motion changes, and hence on the strength of plates, an important question in earthquake physics. Plate location through time is linked to the opening and closing of seaways, which may have influenced climate by dramatically changing global ocean circulation patterns.

\section{Origin of Undersea Volcanoes}

Seamounts are active or extinct undersea volcanoes. They sustain important ecological communities, determine habitats for fish, and act as obstacles to water currents, enhancing tidal energy dissipation and ocean mixing. For all these reasons, it is important to map them. Seamounts come in a range of sizes, and the smaller ones are much more common than the larger ones [Wessel, 2001]. Analysis of the size distribution suggests that a new space-based mapping should increase the number of charted seamounts 18-fold, from roughly 3000 to nearly 60,000 (Figure 7).

Patterns in the geographical distribution of seamounts may settle a debate about the fundamental relationship between volcanism and plate tectonics [Natland and Winterer, 2005]. In basic plate 
theory, plate interiors are geologically inactive, and a "hot spot" theory was added to explain linear volcanic chains in the middles of plates, such as at Hawaii. Although this theory is now enshrined in all introductory textbooks, many scientists are questioning its validity. Some believe it cannot explain all seamount chains, and a few scientists do not believe hotspots exist at all. Alternative explanations include excess magma supply spilling beyond mid-ocean ridges, stretching and cracking of plates, or small-scale convection under plates. A space-based mapping will be required to address the issue, as the seamount distribution pattern can only be revealed by a systematic mapping with a globally uniform resolution of seamount sizes.

\section{Forcasting Tsunamis}

Tsunamis are waves triggered by earthquakes and landslides or, rarely, an unusually large seafloor volcanic eruption [Mofjeld, et al., 2004]. A large tsunami can drive huge waves against the coastlines, endangering people and damaging property in low-lying areas. The tragic Indonesian Tsunami of December 26, 2004 killed more than 200,000 people and left millions homeless. Early warning systems for tsunamis can save lives by allowing people to evacuate, but tsunami forecasts have to be done quickly because tsunamis can traverse the entire ocean basins in just a few hours. Tsunami simulations [Mofjeld, et al., 2001] have shown that relatively small-scale details of deep-ocean bathymetry have a significant impact on tsunami heights because of the cumulative effect of refraction (Figure 8). In many parts of the North Pacific, the predicted maximum tsunami height differs dramatically depending on the resolution of the bathymetry. Further improvements in bathymetry are expected to produce significant improvements in tsunami forecasts, facilitating mitigation in shoreline regions that are frequently endangered and allowing targeted evacuations of at-risk populations. The bathymetry of the Indian Ocean is very poorly sampled by ships and thus a systematic mapping at $10-\mathrm{km}$ resolution is needed to compile a library of tsunami scenarios for rapid consultation in case of another major event. This effort should be completed as soon as possible because major earthquakes are sometimes clustered in time.

\section{Other Applications of Improved Bathymetry}

\section{Continental Margins and Hydrocarbon Exploration}

Geologists call the outermost layer of rocky earth the "crust." Continental crust is much thicker and older than oceanic crust. The margin of the continental crust, which is formed by rifting, is structurally complex and often obscured by thick layers of sediment. Understanding the margins and their sedimentary basins is important because most of the world's oil and gas wealth is formed in basins at the continental margins, and because new international law allows new territorial claims in this area.

In the deep ocean, where the crust is young and the overlying sediments are thin, ocean surface gravity anomalies observable from space are easily correlated with bathymetry. The situation is 
different at the continental margins where sediments are thick and the underlying rocks are of variable density and thickness. Here, gravity anomalies are often poorly correlated with bathymetry. Despite the lack of direct correlation between bathymetry and gravity at a margin, the gravity data obtained from a new space bathymetry mission would dramatically improve our understanding of the variety of continental margins in several ways. Gravity anomalies reveal mass anomalies and their compensation; these can be interpreted to reveal sediment types and basin locations [Fairhead, et al., 2001]. A uniform, high-resolution gravity mapping continuous from the deep ocean to the shallow shelf will make it possible to follow fracture zones and other structures out of the ocean basin onto the adjacent continent, to define and compare segmentation of margins along their length, and to indicate the position of the continent-ocean boundary. Rifted, fault-bounded blocks of continental crust often have dimensions of 5-25 km by 20-100 $\mathrm{km}$. The shapes of these blocks must be seen in three dimensions to understand rifting tectonics. These individual blocks are not resolved in current data but would be mapped by the proposed space bathymetry mission. While current altimeter data delineate the large offshore basins and major structures, they do not resolve some of the smaller geomorphic features, including the smaller basins. Spatial scales shorter than $20 \mathrm{~km}$ in the presently available data cannot be interpreted with confidence close to shore, as the raw altimeter data are often missing or unreliable near the coast. The exploration industry would benefit from altimeter data with as much resolution as possible and extending as near-shore as possible.

\section{Law of the Sea Definition of the Continental Shelf}

One of the many objectives of the United Nations Convention on the Law of the Sea is to subdivide ocean space into zones under the jurisdiction of a Coastal State or of the International Seabed Authority. Coastal States may claim territorial rights to the seabed and its resources beyond their traditional Exclusive Economic Zones by submitting a claim to a Juridical Continental Shelf. This shelf represents a seaward prolongation of a State's territory and must be delineated according to a complex legal formula prescribed in Article 76 of the Convention. Bathymetry from Space can potentially contribute to resolving one element of the formula, the $2500 \mathrm{~m}$ isobath [Monahan, 2004]. Altimetry can also contribute to the problem of determining the location of the foot of the slope. Such uses of altimetric data are consistent with the view expressed by the Commission on the Limits of the Continental Shelf that altimetric data will be considered admissible as supporting information in a submission.

Although publications on space bathymetry caution that the technique may not be most accurate in continental slope and rise areas, it seems to be accurate enough for the purpose of determining a Juridical Continental Shelf under Article 76. A joint U.S.-Canadian study compared the location of the $2500 \mathrm{~m}$ isobath as measured by acoustic swath bathymetry from a GPS-navigated ship survey, and as estimated from the space bathymetry technique using existing satellite data. The study found that the location discrepancies between the two techniques were small enough to be within International Hydrographic Organization guidelines for errors in bathymetric surveys. To maximize the territory claimed, the Convention allows Coastal States to select data emphasizing seaward protrusions of their shelves. Thus, it is likely that space bathymetry will be used for reconnaissance of areas where a State might profitably invest in more detailed ship surveys. 


\section{Inertial Navigation}

A passenger in a moving vehicle can perceive changes in the vehicle's velocity (direction or speed), because they cause the passenger's body to lean in the direction opposite the change. Inertial navigation systems work the same way, computing the motion of a vehicle by sensing accelerations on it. Precise inertial navigation systems require knowledge of gravity anomalies; otherwise a tilt of the direction of gravity (Figure 3) is mistaken for a turn of the vehicle.

Advanced integrated navigation systems now in use on some ships and aircraft require knowledge of anomalies in the direction of gravity at the 0.5 arc-second ( 2 microradians) level for optimum performance. Military data supporting this requirement were collected over limited areas of Earth during the Cold War. A systematic global data set of this quality does not yet exist. The measurements that a new bathymetry from space mission would obtain-sea surface slopes to 1 microradian - will allow computation of the gravity de-flection angles at sufficient precision to support precise inertial navigation at sea over nearly the entire globe.

\section{Implementation}

Current space bathymetry can resolve $12 \mathrm{~km}$ on rough seafloor and only $20 \mathrm{~km}$ on smooth seafloor. A new mission with sufficient accuracy to resolve 6-9 km would capture most of the interesting geophysics of seafloor spreading and the statistical properties of the finer-scale roughness.

\section{Current Limitations and Future Requirements}

The laws of physics impose a fundamental limit on the resolution of the topography that can be inferred from sea surface gravity to about twice the regional ocean depth, which is $6-9 \mathrm{~km}$ in the deep ocean. This physical limit has not yet been achieved from satellite altimetry because the ocean surface is roughened by waves that are typically $2-4 \mathrm{~m}$ tall. Conventional radar altimeters illuminate a spot on the ocean surface that is large enough to average out some of the local irregularities due to ocean waves. The noise is further reduced by averaging a thousand pulses over a $6 \mathrm{~km}$ distance along the satellite track. Attaining the physical limit will require a factor of five improvement in the accuracy of the global sea surface slope, which can be achieved through a combination of improved radar technology and multiple mappings. We envision a new mission with the following characteristics:

Altimeter precision. The most important requirement is improvement in ranging technology to achieve at least a factor of two enhancement in range precision (with respect to older altimeters such as GEOSAT and TOPEX) in a typical sea state of $3 \mathrm{~m}$. In shallow water, where upward continuation is minor, and in calm seas where waves are not significant, it will also be important to have an along-track footprint that is much less than one-half of the resolution. This footprint is smaller than the standard pulse-limited footprint of GEOSAT or TOPEX, so new technology must be used. 
Mission duration. The GEOSAT Geodetic Mission (1.5 years), which has superior range precision to the ERS-1 Geodetic Mission [Yale, et al., 1995] (1 year), provided a single mapping of the oceans at $\sim 5 \mathrm{~km}$ track spacing. Since the measurement noise scales as the square root of the number of measurements, a six-year mission could reduce the error by an additional factor of two.

Moderate inclination. The short, non-repeat orbit phases of the Geosat and ERS-1 altimeters had relatively high inclination $\left(72^{\circ}\right.$ GEOSAT, $82^{\circ}$ ERS $)$ and thus poor accuracy of the eastwest slope at the equator. A new mission should have an inclination of $\sim 60^{\circ}$ to improve east-west slope recovery. This, combined with the other improvements, will meet the factor of five requirement.

Near-shore tracking. For applications near coastlines, the ability of the instrument to track the ocean surface close to shore, and acquire the surface soon after leaving land, is desirable.

It should be stressed that the basic measurement is not the height of the ocean surface but the slope of the ocean surface to an accuracy of better than 1 microradian ( $1 \mathrm{~mm}$ height change over 1 $\mathrm{km}$ horizontal distance). The need to resolve height differences, and not heights, means that the mission can be much cheaper than other altimeter missions and can take advantage of a spacecraft platform that is less stable than other missions require. The 1 microradian slope precision can be achieved without measuring radar propagation delays in the ionosphere and troposphere, as the slopes of these corrections are negligible. These factors reduce the cost and complexity of the spacecraft with respect to a ty pical altimeter optimized for recovery of ocean currents.

Delay-Doppler altimeter technology. A delay-Doppler radar altimeter such as planned for CryoSat II can deliver the required height precision and spatial resolution. This innovative satellite altimeter uses signal processing strategies borrowed from synthetic aperture radar to improve height measurement precision by a factor of two, and to reduce along-track footprint size by a factor of five or more, in marked contrast to a conventional radar altimeter. Unfortunately the CryoSat ground segment cannot capture the full SAR waveforms globally so it will be operated as a conventional altimeter over the oceans. Onboard processing, to reduce the data transmission requirements, has been demonstrated in a delay-Doppler altimeter built by the Johns Hopkins University Applied Physics Laboratory (JHU APL) and flight-tested on Naval Research Laboratory (NRL) and National Aeronautics and Space Administration (NASA) P-3 aircraft. A preliminary design study by JHU APL for the National Oceanic and Atmospheric Administration (NOAA) suggests that a delay-Doppler space bathymetry mission could be completed for approximately $\$ 60 \mathrm{M}$, plus launch costs.

Acknowledgements. This material is based upon work supported by the National Science Foundation under Grant No. 0326707 


\section{Figure captions}

\section{Légendes des figures}

Figure 1. The Pacific-Antarctic rise, which has an area about equal to North America, is a broad rise of the ocean floor caused by sea floor spreading between two major tectonic plates. To the west of the ridge lies the Louisville seamount chain which is a chain of large undersea volcanoes having a length equal to the distance between New York and Los Angeles. These features are unfamiliar because they were unknown 30 years ago [Menard and Smith, 1966]. The Louisville seamount chain was first detected in 1972 using depth soundings collected along random ship crossings of the South Pacific. Six years later the full extent of this chain was revealed by a radar altimeter aboard the Seasat (NASA) spacecraft [Haxby, et al., 1983]. Recently, high density data collected by the Geosat (US Navy) and ERS-1 (European Space Agency) spacecraft data show the Pacific-Antarctic Rise and the Louisville Ridge in unprecedented detail [Smith and Sandwell, 1997].

Figure 1. La dorsale Pacifique-Antarctique - un vaste relief de la taille de l'Amérique du Nord - est produite par accrétion de croûte océanique entre les plaques Pacifique et Antarctique. Sur le flanc ouest de la dorsale, s'étend une chaîne de volcans sous-marins - dite chaîne de Louisville - sur une distance équivalente à la largeur (Est-Ouest) des Etats-Unis. Découvertes relativement récemment (voir en haut à gauche, la carte de [Menard et Smith, 1965]), ces structures sont peu connues des non-spécialistes. La chaîne de Louisville a été détectée en 1972, à partir de levés bathymétriques exploratoires épars la recoupant. L'étendue de la chaîne a été vue dans son ensemble six plus tard, grâce aux données altimétriques de SeaSat de la NASA [Haxby et al, 1983]. Les données altimétriques acquises par les satellites GeoSat (US Navy) et ERS-1 (Agence Spatiale Européenne) révèlent des détails des structures dans des zones vierges de tout levé bathymétrique.

Figure 2. Modern tools for mapping the deep ocean floor. A) A shipboard multibeam echo sounders uses sound waves to map 10-20 km wide swaths at 200 horizontal resolution. B) An Earth-orbiting radar cannot see the ocean bottom, but it can measure ocean surface height variations induced by ocean floor topography. While the resolution of the echo sounder technique is far superior to the ultimate resolution of the satellite altimeter technique $(\sim 8 \mathrm{~km})$, complete mapping of the deep oceans using ships would take 200 ship-years at a cost of billions of dollars [Carron, et al., 2001]. Indeed, the shipboard and altimeter methods are highly complementary. The current distribution of ship soundings provides the long-wavelength $(>160 \mathrm{~km})$ information that cannot be obtained from gravity because of spatial variations in isostasy (Figure 3). Satellite altimeters provide the global uniform coverage in the 16 to 160 $\mathrm{km}$ wavelength band. When interesting features are discovered in satellite gravity, they can be surveyed in fine detail by ships.

Figure 2: Outils modernes de cartographie du plancher océanique. A) Les sondeurs acoustiques multifaisceaux permettent de couvrir, à chaque passage du navire, une bande de plancher océanique de 10 à $20 \mathrm{~km}$ de large, avec une résolution horizontale de l'ordre de $200 \mathrm{~m}$. B) Les ondes des altimètres-radar ne penètrent pas à l'intérieur de la masse d'eau, mais peuvent mesurer les variations de la surface moyenne des océans engendrées par la topographie sous-marine. La résolution des sondages acoustiques est très largement supérieure à celle que l'on peut espérer atteindre avec les modèles déduits de l'altimétrie ( $\sim \mathrm{km}$ dans le meilleur des cas). Il faudrait cependant l'équivalent de 200 années de temps-navire pour couvrir l'ensemble des grands fonds océaniques, ce qui représente eds coûts de plusieurs milliards de dollars [Carron, et al., 2001]. L'altimétrie et l'acoustique sont complémentaires à plusieurs titres. En effet, sur le plan global, les données bathymétriques actuelles fournissent les grandes longueurs d'onde (> $160 \mathrm{~km}$ ) de la topographie du plancher océanique, qui ne peuvent pas être obtenues de la gravimétrie satellitaire, du fait des variations latérales du mode de compensation isostatique. Les satellites altimétriques fournissent une couverture globale de la topgraphie aux longueurs d'onde comprises entre 16 et $160 \mathrm{~km}$. Les structures intéressantes détectées par satellite peuvent ensuite être étudiées en détail avec des navires équipés de sondeurs acoustiques.

Figure 3. Satellite-derived bathymetry. A) A mountain on the ocean floor adds to the pull of Earth's gravity and changes its direction subtly, causing extra water to pile up around the mountain. The tilt in the direction of gravity, called a "deflection of the vertical," is equal to the slope of the sea surface, and is measured in microradians. One microradian of deflection appears as a $1 \mathrm{~mm}$ change in sea surface height per $1 \mathrm{~km}$ of horizontal distance. Laplace's 
equation allows the exact transformation of sea surface slope into gravity anomaly. One microradian error in slope translates into approximately 1 milligal (mgal) error in gravity. B) Over areas of thin sediment cover, the ratio of topography to gravity is primarily a function of topographic wavelength. A gravity field that is accurate to 1 milligal can recovery topography between wavelengths of $16 \mathrm{~km}$ and $160 \mathrm{~km}$ to an accuracy of better than $70 \mathrm{~m}$. The short-wavelength part of the transfer becomes singular because of the smoothing of gravity by upward continuation. The long-wavelength part of the transfer becomes singular because isostatic compensation cancels the long-wavelength gravity due to seafloor topography. For wavelengths $>160 \mathrm{~km}$, the topography/gravity ratio is highly dependent on the elastic thickness of the lithosphere so gravity cannot be uniquely inverted for topography. Both ship soundings and satellite altimeter data are needed to provide a global mapping of the seafloor topography. Existing sparse ship soundings are sufficient to constrain the long-wavelength $(>160 \mathrm{~km})$ shape of the oceans. Ship soundings are also used to calibrate the topography to gravity ratio in over the intermediate wavelength band (160$16 \mathrm{~km})$. Shorter wavelength topography $(<12-18 \mathrm{~km})$ can only be recovered by swath bathymetry surveys. The resolution of seafloor structure within the achievable band of spatial is a strong function of the signal-to-noise ratio in the altimeter data, and a new mission with a more precise altimeter would make improvements of a factor of 5 in vertical precision, 2 to 3 in horizontal length, and 4 to 9 in horizontal area.

Figure 3. Bathymétrie déduite de l'altimétrie satellitaire. A) Dans l'océan, les masses d'eau ont tendance à s'accumuler au dessus des montagnes sous-marines à cause de l'attraction causée par les reliefs. Ainsi, en l'absence de vent, vagues et courants marins, il y a naturellement des «bosses » à l'aplomb des monts sous-marins et des «creux » au dessus des fosses : c'est cette propriété qui est utilisée par les satellites pour estimer, de manière approchée, la hauteur des reliefs sous-marins. La surface de l'océan au repos (en l'absence de toute perturbation océanique) correspond au géoïde, une surface équipotentielle en tous points perpendiculaire à la force de pesanteur locale. La déflection de la verticale résultant des reliefs est égale à la pente du géoïde. Elle est mesurée en microradians (un microradian équivaut à $1 \mathrm{~mm}$ de variation de hauteur du géoïde par kilomètre de distance horizontale). L'équation de Laplace permet de convertir hauteur de géoïde en anomalie de gravité. Une erreur de pente d'un microradian équivaut à $1 \mathrm{mGal} \mathrm{d'erreur} \mathrm{en} \mathrm{gravité.} \mathrm{B)} \mathrm{Dans} \mathrm{les} \mathrm{zones} \mathrm{où} \mathrm{la} \mathrm{couverture} \mathrm{sédimentaire} \mathrm{est}$ faible, le rapport entre gravité et topographie sous-marine dépend de la longueur d'onde de la topographie. Avec des anomalies gravimétriques précises à $1 \mathrm{mGal}$ près, on peut déterminer la topographie avec une précision de l'ordre de 70 mètres pour les longueurs d'onde comprises entre 16 et $160 \mathrm{~km}$. Une anomalie de topographie sous-marine de très courte longueur d'onde est à peine décelable (quasi nulle) à la surface de l'océan à cause de l'épaisseur de la masse d'eau ; ainsi, aux courtes longueurs d'onde, le rapport entre topographie et gravité (T/G) part à l'infini (en langage mathématique, c'est le résultat de l'opération dite de «continuation vers le haut»). Aux grandes longueurs d'onde (> $160 \mathrm{~km}$ ), la topographie est compensée par des anomalies de masse en profondeur (situées sous la la croûte), si bien que la topographie et la gravité ne sont plus vraiment corrélés. C'est pourquoi il est nécessaire d'avoir à la fois des données bathymétriques acquises par bateau et des données altimétriques pour déterminer la topographie des fonds océaniques à l'échelle globale. Les données bathymériques existantes sont suffisantes pour contraindre les grandes longueurs d'onde $(>160 \mathrm{~km})$ de la topographie sous-marine. Ces données permettent également de calibrer le rapport T/G dans la bande comprise entre 16 et $160 \mathrm{~km}$. Pour obtenir le detail de la topographie (aux longueurs d'ondes $<12-18 \mathrm{~km}$ ), une couverture bathymétrique totale, au moyen de sondeurs multifaisceaux. La resolution dans la bande $[16-160 \mathrm{~km}]$ depend de la precision (rapport signal / bruit) des données altimétriques. L'amélioration du rapport S/B d'un facteur 4 permettrait d'améliorer significativement l'estimation de la topographie dans cette gamme de longueurs d'onde.

Figure 4 (upper) Measured bathymetry (right column) and predicted bathymetry (left and center columns) for representative topography on the Mid-Atlantic Ridge, the East Pacific Rise, and the Gulf of Mexico. The MidAtlantic Ridge and East Pacific Rise show the characteristic abyssal-hill signature of slow and fast spreading ridges, respectively. While the current predicted bathymetry in the Gulf of Mexico is unable to resolved the salt-related mini-basins (outlined), the future predicted bathymetry reveals some of the more important structures; a global data set would be beneficial in frontier reconnaissance studies.

(lower) East-west spectra of the Mid-Atlantic Ridge and the East Pacific rise area bathymetry. For both areas, the corner wavenumber and roll-off exponent are $20 \mathrm{~km}$ and -2.8 , respectively. The total power is $493 \mathrm{~m}$ for the MAR and $209 \mathrm{~m}$ for the EPR. The noise spectra (dotted curves) for current and future bathymetric prediction is discussed in the following section. A signal to noise ratio of 1 defines the resolution limits of current and future bathymetric prediction. The current resolution for rough and smooth seafloor is $25 \mathrm{~km}$ and $45 \mathrm{~km}$, respectively. Assuming a factor of 5 noise reduction in a future mission, the resolution improves to 12 and $17 \mathrm{~km}$, respectively (i.e., 6-9 km half-wavelength). Note this improvement captures the corner wavenumber of $20 \mathrm{~km}$. 
Figure 4. Haut : bathymétrie mesurée (colonne de droite) et predite (colonnes du milieu et de gauche) pour différents cas representatifs provenant des dorsales Médio-Atlantique ou Est-Pacifique et du Golfe du Mexique. Les flancs des dorsales exhibent la signature caractéristique des collines abyssales produites à l'axe des dorsales lentes ou rapides, respectivement. La bathymétrie prédite actuelle ne permet pas de délimiter les mini-bassins associés aux diapirs de sel dans le Golfe de Mexico, mais un meilleur rapport S/B des données altimétriques permettrait d'obtenir un nouveau modèle bathymétrique présentant des améliorations significatives.

Bas : Aire (représentée dans le domaine spectrale) de sections bathymétriques caractéristiques perpendiculaires à l'axe des dorsales Médio-Atlantique ou Est-Pacifique. Pour les détails, voir ci-dessus la légende en anglais, intraduisible en français courant.

Figure 5. The availability of accurate bathymetric data is critical for modeling major current systems such as the Kuroshio in the North Pacific [Metzger and Hurlburt, 2001]. The simulation in the left panel properly represents the islands and shoals within the Luzon Strait and the intrusion of the Kuroshio into the South China Sea. If the three model grid points representing small topographic features are removed (marked in blue on the left panel), the Kuroshio intrudes farther west (right panel) than indicated by observations.

Figure 5. La précision des modèles batymétriques s'avère être d'une grande importance pour la modélisation des grands courants océaniques, tels que le Kuroshio dans le Pacifique Nord [Metzger and Hurlburt, 2001]. La simulation du panneau de gauche a été réalisée avec le modèle complet de topographie globale. Elle est relativement conforme aux observations. Si l'on retire les trois noeuds de la grille indiqués en bleu sur le panneau de gauche, on obtient (panneau de droite) que le Kuroshio pénètre plus profondément vers l'ouest à l'intérieur de la mer de Chine par le détroit de Luzon, ce qui correspond pas aux données.

Figure 6. Mixing rates in the ocean govern the rate at which the ocean absorbs heat and greenhouse gases, moderating climate. Global climate change forecasts are uncertain in part due to uncertainty in the global average ocean mixing rate. Mixing rates in the ocean vary geographically depending on bottom roughness [Polzin, et al., 1997]. (upper) Bathymetry of Brazil Basin, South Atlantic derived from ship soundings lacks the resolution needed to distinguish between rough and smooth seafloor. (center) Bathymetry derived from satellite altimetry and ship soundings resolves the rough seafloor associated with fracture zones but not abyssal hills. (lower) Mixing rates observed during an oceanographic survey across the Brazil Basin in the South Atlantic Ocean. Low mixing rates (purple) were found over the smooth topography to the west, and higher mixing rates (multiple colors) over the rough topography to the east.

Figure 6. L'absorption par l'océan de la chaleur et des gaz à effet de serre dépend de la façon dont se mélangent les différentes masses d'eau. La modélisation du changement climatique global dépend donc, elle aussi, de la vigueur de ces mélanges qui varient en fonction de la rugosité du plancher océanique [Polzin, et al., 1997]. (Panneau du haut) La topographie du bassin du Brésil (Atlantique Sud) déterminée à partir des seules données bathymétriques ne permet pas de déterminer la rugosité du fond. (Panneau du milieu) La topographie déduite de la combinaison des données bateau et des données altimétriques actuellement disponibles ne permet d'accéder à la rugosité associée à la présence des zones de fracture, mais pas à celle liée aux collines abyssales. (Panneau du bas) Taux de mélange des masses d'eau observés in situ. Les taux de mélange les plus faible (violet) apparaissent dans les zones où la topographie est plutôt lisse ; les taux les plus élevés, là où la topographie est le plus accidentée. 
Figure 7. Seamounts come in a range of sizes. The red dots shown here indicate the number of seamounts found with existing satellite altimeter data, as a function of seamount size [Wessel, 2001]. For seamounts $2 \mathrm{~km}$ tall and larger, the data are explained by a scaling rule (solid line). For heights less than $2 \mathrm{~km}$, the red dots fall off the line because these more numerous small seamounts fall below the resolution of existing data. A new Bathymetry from Space mission should find these unmapped seamounts. An improvement in altimeter height resolution by a factor of 2 should increase the total number of seamounts mapped by 18 -fold. The newfound seamounts will have important ramifications for physical oceanography, marine ecology, fisheries management, and fundamental science questions about Earth's magma budget and the relationship between volcanism and tectonics.

Figure 7. Classification (par taille) des monts sous-marins. Les points rouges indiquent les monts localisés à partir des données altimétriques existantes [Wessel, 2001]. La ligne continue noire représente une droite de régression effectuée à partir des données bathymétriques réelles, montrant que le nombre de monts diminue exponentiellement avec leur taille. La corrélation avec les données déduites de l'altimétrie est satisfaisante pour les releifs de hauteur supérieure à $2 \mathrm{~km}$, mais pas en dessous, ce qui suggère qu'il reste encore de nombreux monts sous-marins à découvrir, dont la hauteur est inférieure à $2 \mathrm{~km}$. Une nouvelle mission altimétrique dédiée permettrait d'inventorier une bonne partie de ces monts sous-marins. L'inventaire complet des monts-sous marins apporterait des éléments nouveaux dans de nombreux domaines de recherche appliquée (océanographie physique, écologie marine, halieutique), mais aussi fondamentale (géodynamique, bilan magmatique de la Terre, interactions entre volcanisme et tectonique).

Figure 8. Tsunamis are catastrophic shock waves that can flood coastal areas after a submarine earthquake or landslide. A submarine event on one side of an ocean basin can flood the coasts on the other side in a matter of hours. Careful modeling of the propagation and refraction of these waves is a key component of hazard mitigation. Model studies have shown that lack of information about the small-scale bathymetry of the ocean floor makes the estimated height of the flooding wave uncertain by $100 \%$ or more [Mofjeld, et al., 2004]. Here is a model of the tsunami generated by the December 5, 1977 earthquake in Kamchatka. Blue regions in the open ocean show the tsunami spreading outward, like a wave that forms after dropping a pebble into a pond. Rainbow colors indicate the percent change in amplitude attributed to fine-scale bathymetry. Image courtesy H.O. Mofjeld, NOAA PMEL.

Figure 9, d'après H.O. Mofjeld, NOAA PMEL Les tsunamis sont des ondes de gravité, principalement dues à des séismes ou à des glissements de terrain. Les systèmes d'alerte reposent sur le fait que les tsunamis se propagent bien plus lentement que les ondes sismiques. On peut donc en principe déclencher l'alerte avant l'arrivée de la vague. Pour affiner l'alerte (et éviter les fausses alarmes), il serait intéressant de pouvoir modéliser la hauteur de la vague, avant qu'elle n'arrive à la côte. Pour ce faire, il est nécessaire d'avoir un modèle bathymétrique aussi précise que possible. Des études réalisées par [Mofjeld, et al., 2004] montrent que les estimations de la hauteur de vague à la côte peuvent varier de $100 \%$, suivant le modèle bathymétrique qu'on utilise. La figure ci-dessus indique une simulation de la hauteur de vague engendrée par le séisme survenu le 5 décembre 1977 au large du Kamtchatka. La simulation montre que le tsunami se propage comme une onde après un jet de pierre dans une mare. Les couleurs indiquent le rapport (exprimé en pourcentage) entre la hauteur de vague calculée avec un océan plat et celle calculée avec le modèle global de bathymétrie déduit des données satellitaires. 




Figure 1 

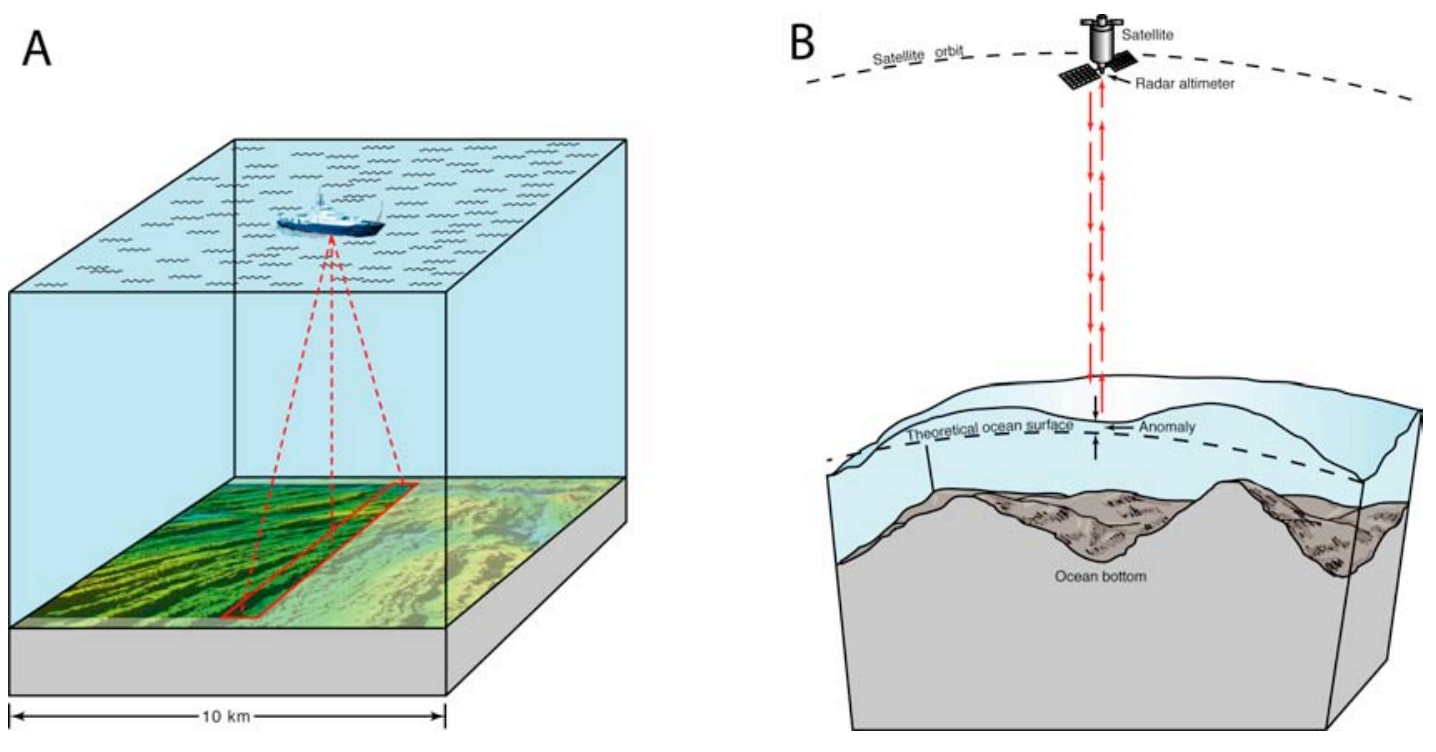

Figure 2 

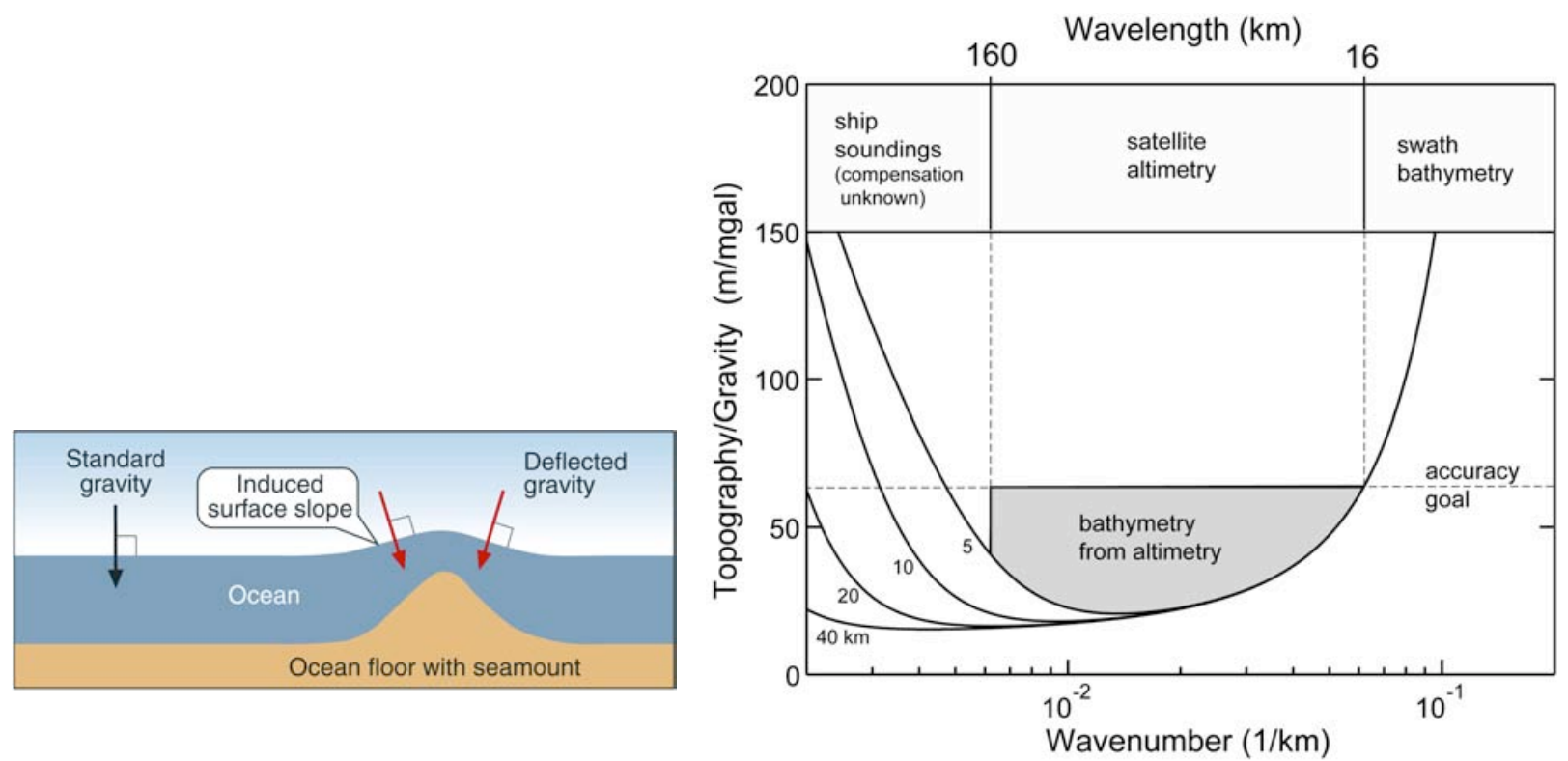

Figure 3 


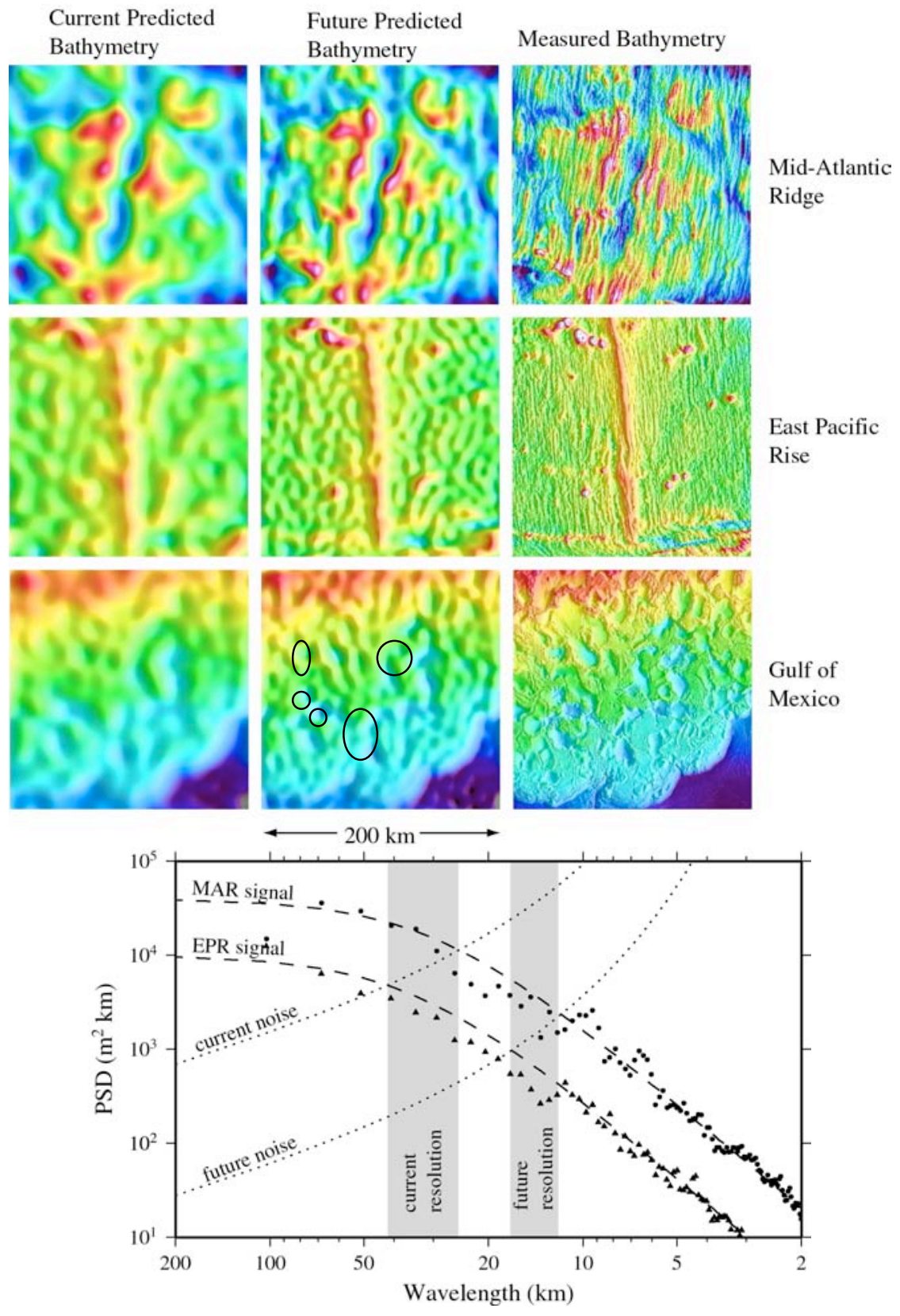

Figure 4 


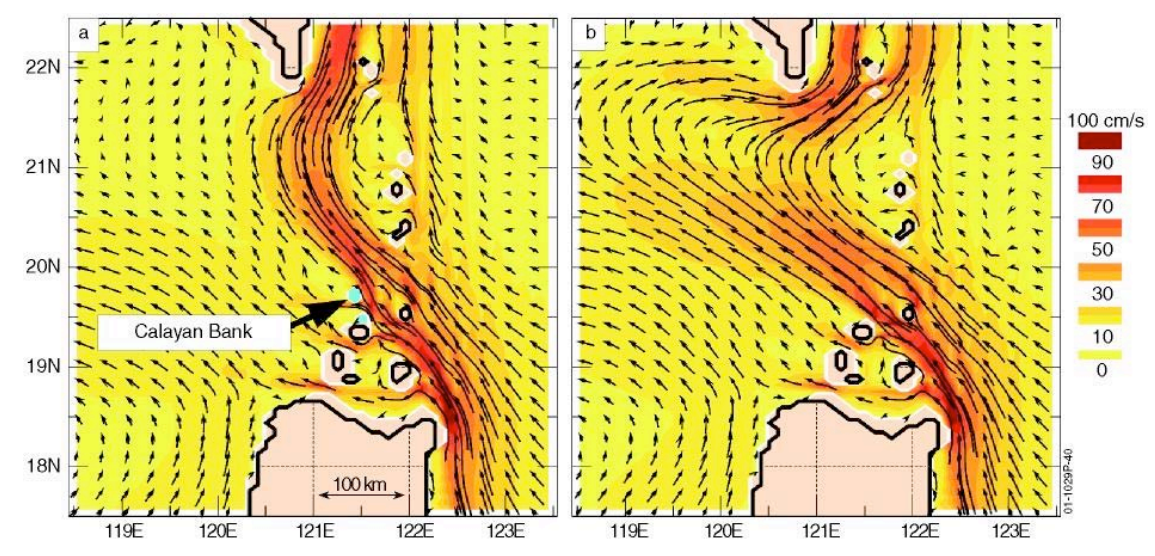

Figure 5 


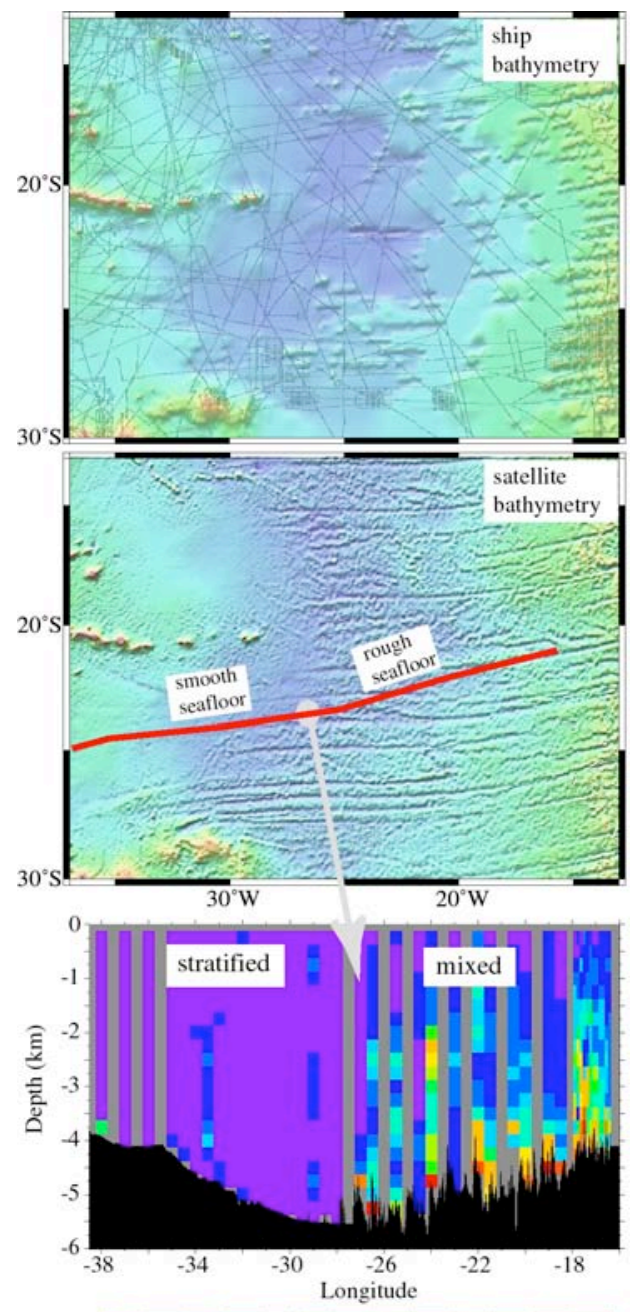

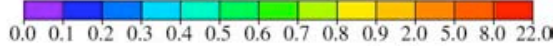
Vertical Diffusivity $\left(10^{-4} \mathrm{~m}^{2} \mathrm{~s}^{-1}\right)$

Figure 6 




Figure 7 


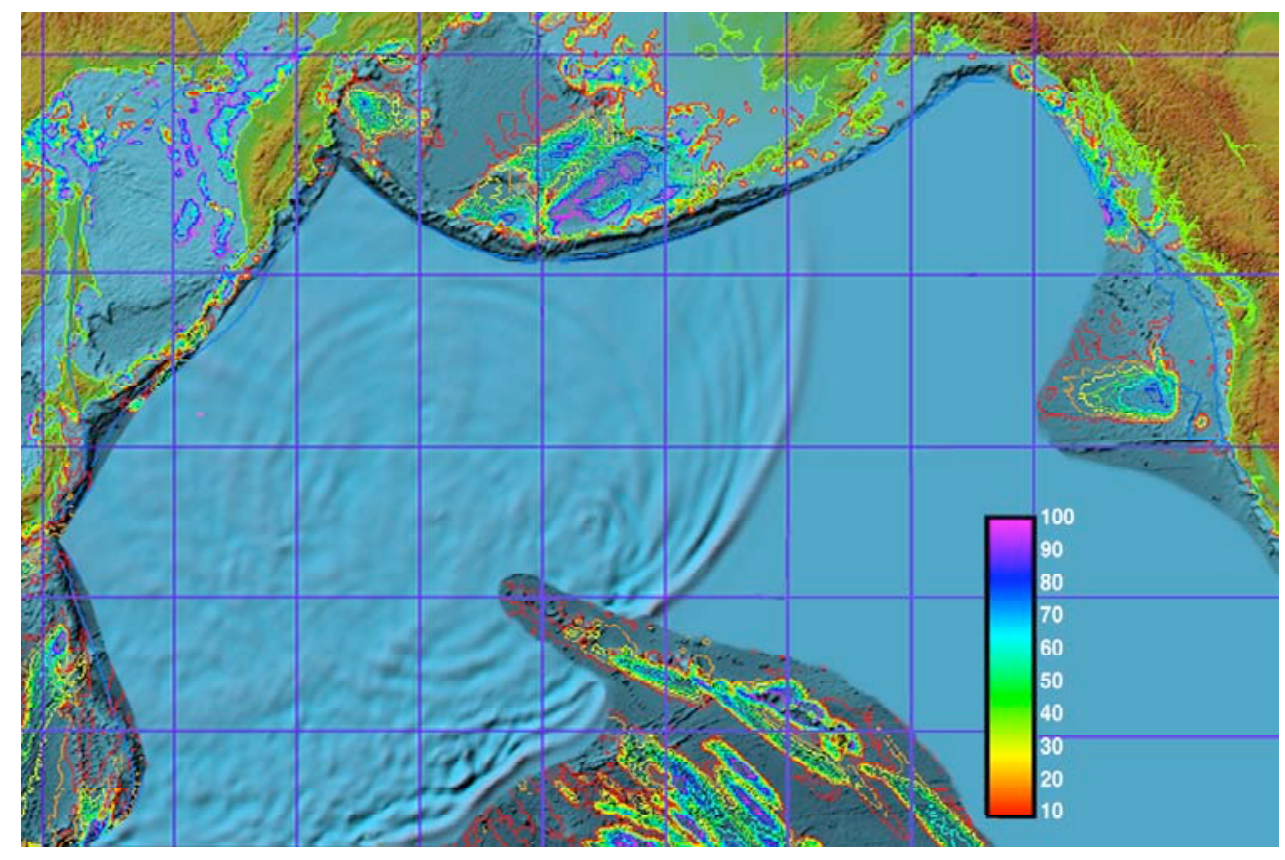

Figure 8 


\section{References}

Baudry, N., and S. Calmant (1991), 3-D Modelling of seamount topography from satellite altimetry, Geophys. Res. Lett., 18, 1143-1146.

Brown, J., et al. (1998), The Ocean Basins: Their Structure and Evolution, 171 pp., Pergamon Press, Oxford.

Carron, M. J., et al. (2001), A proposed international long-term project to systematically map the world's ocean floors from beach to trench: GOMaP (Global Ocean Mapping Program), Inter. Hydr. Rev., 2, 49-50.

Cazenave, A., et al. (1996), High-resolution mean sea surface computed with altimeter data of ERS-1 (Geodetic Mission) and TOPEX-POSEIDON, Geophys. J. Int., 125, 696-704.

Dixon, T. H., et al. (1983), Bathymetric prediction from Seasat altimeter data, J. Geophys. Res., 88, 1563-1571.

Fairhead, J. D., et al. (2001), Satellite-derived gravity having an impact on marine exploration, in The Leading Edge, edited, pp. 873-876.

Gille, S. T., et al. (2004), Seafloor topography and ocean circulation, Oceanography, 17, 47-54.

Haxby, W. F., et al. (1983), Digital images of combined oceanic and continental data sets and their use in tectonic studies, EOS Trans. Amer. Geophys. Un., 64, 995-1004.

Jayne, S. R., et al. (2004), Connections between ocean bottom topography and the Earth's Climate, Oceanography, 17, 65 - 74.

Jung, W. Y., and P. R. Vogt (1992), Predicting bathymetry from Geosat-ERM and shipborne profiles in the South Atlantic ocean, Tectonophysics, 210, 235-253.

Kunze, E., and S. G. Llewellyn Smith (2004), The role of small-scale topography in turbulent mixing of the global ocean, Oceanography, 17, 55 - 64.

Menard, H. W., and S. M. Smith (1966), Hypsometry of Ocean Basin Provinces, J. Geophys. Res., 71, 4305-4325.

Metzger, E. J., and H. E. Hurlburt (2001), The importance of high resolution and accurate coastline geometry on modeling South China Sea inflow, Geophys. Res., Lett., 28, 1059-1062.

Mofjeld, H. O., et al. (2004), Tsunami scattering and earthquake faults in the deep Pacific Ocean, Oceanography, 17, 38-46.

Mofjeld, H. O., et al. (2001), Tsunami scattering provinces in the Pacific Ocean, Geophys. Res. Lett., 28, 335-337.

Monahan, D. (2004), Altimetry applications to continental shelf delineation under the United Nations Convention on the Law of the Sea, Oceanography, 17, 75-82.

Mueller, R. D., et al. (1997), Digital isochrons of the world's ocean floor, J. Geophys. Res., 102, 3211-3214.

Munk, W., and C. Wunch (1998), Abyssal recipes II: Energetics of today and wind mixing, Deep-Sea Res. I, 45, 1977-2010.

Naar, D. F., and R. N. Hey (1989), Speed limit for oceanic transform faults, Geology, 17, 420422.

Natland, J. H., and E. L. Winterer (2005), Fissure control on volcanic action in the Pacific, in Plates, plumes, and paradigms: Geological Society of America Special Paper 388, edited by G. R. Foulger, Natland, J.H., Presnall, D.C., and Anderson, D.L.,, pp. 687 - 710, Geological

Society of America.

Polzin, K. L., et al. (1997), Spatial variability of turbulent mixing in the abyssal ocean, Science, 276, 93-96. 
Ramillien, G., and A. Cazenave (1997), Global bathymetry derived from altimeter data of the ERS-1 Geodetic Mission, .J. Geodynamics, 23, 129-149.

Sandwell, D. T., and W. H. F. Smith (1997), Marine gravity anomaly from Geosat and ERS-1 satellite altimetry, J. Geophys. Res., 102, 10039-10054.

Smith, W. H. F. (1998), Seafloor tectonic fabric from satellite altimetry, Ann, Rev. Earth Planet. Sci., 26, 697-738.

Smith, W. H. F., and D. T. Sandwell (1994), Bathymetric prediction fron dense satellite altimetry and sparse shipboard bathymetry, J. Geophys. Res., 99, 21803-21824.

Smith, W. H. F., and D. T. Sandwell (1997), Global sea floor topography from satellite altimetry and ship depth soundings, Science, 277, 1956-1961.

Tapley, B. D., and M. C. Kim (2001), Applications to Geodesy, in Satellite Altimetry and Earth Sciences, edited by b. L.-L. F. a. A. Cazenave, pp. 371-403, Academic Press, New York.

Wessel, P. (2001), Global distribution of seamounts inferred from gridded Geosat/ERS-1 altimetry, J. Geophys. Res., 106, 19,431-419,441.

Wessel, P., and S. Lyons (1997), Distribution of large Pacific seamounts from Geosat/ERS 1: implications for the history of intraplate volcanism, J. Geophys. Res., 102, 22459-22475.

Yale, M. M., et al. (1995), Comparison of along-track resolution of stacked Geosat, ERS-1 and TOPEX satellite altimeters, J. Geophys. Res., 100. 